\title{
Weldability of 9Cr-ODS and JLF-1 Steels for Dissimilar Joining with Hot Isostatic Pressing and Electron Beam Welding*)
}

\author{
Haiying FU ${ }^{1)}$, Takuya NAGASAKA ${ }^{1,2)}$, Takeo MUROGA ${ }^{1,2)}$, Wenhai GUAN ${ }^{3)}$, Shuhei NOGAMI ${ }^{3)}$, \\ Akira HASEGAWA $^{3)}$ and Hisashi SERIZAWA ${ }^{4)}$ \\ ${ }^{1)}$ SOKENDAI (The Graduate University for Advanced Studies), 322-6 Oroshi-cho, Toki 509-5292, Japan \\ ${ }^{2)}$ National Institute for Fusion Science, 322-6 Oroshi-cho, Toki 509-5292, Japan \\ ${ }^{3)}$ Tohoku University, 6-6-01-2 Aramaki-aza-Aoba, Aoba-ku, Sendai 980-8578, Japan \\ 4) Joining and Welding Research Institute, Osaka University, 11-1 Mihogaoka, Ibaraki 567-0047, Japan
}

(Received 24 November 2014 / Accepted 23 January 2015)

\begin{abstract}
Dissimilar joints between 9Cr-ODS and JLF-1 were fabricated by hot isostatic pressing (HIP) and by electron beam welding (EBW), respectively. Compared to the $\mathrm{HIP}$ at $1000^{\circ} \mathrm{C}, \mathrm{HIP}$ at higher temperatures of $1050^{\circ} \mathrm{C}$ and $1100^{\circ} \mathrm{C}$ is effective to improve the joining strength of the joints. All the as-HIPed joints fractured at the interface during tensile tests. $1050^{\circ} \mathrm{C}$-HIP showed the best joining strength and reduction of area. Post-weld heat treatment (PWHT) with normalization and tempering (N\&T) could further improve the joining properties of the HIPed joints. The joints fractured outside the interface at the JLF-1 base metals. EBW showed better weld-ability than HIP, because the joint made by EBW did not fracture at the weld metal during tensile tests, but always fractured at JLF-1 side. However, the properties of the HIPed joints were improved after PWHT with N\&T, and were comparable to that made by EBW.
\end{abstract}

(C) 2015 The Japan Society of Plasma Science and Nuclear Fusion Research

Keywords: hot isostatic pressing, electron beam welding, post-weld heat treatment, joining strength

DOI: $10.1585 /$ pfr. 10.3405015

\section{Introduction}

Because of their excellent mechanical properties at high temperatures, ODS-RAFM (oxide-dispersionstrengthened reduced activation ferritic/martensitic) steels could be utilized as part of structure materials of first wall blanket in a fusion reactor [1-4], by joining with conventional RAFM steels to enhance the allowable application temperature of blanket systems. Thus dissimilar joining between ODS-RAFM steels and conventional RAFM steels is very essential to the construction of advanced fusion blanket systems applied with ODS-RAFM steels. In the world, several dissimilar joining techniques between ODS-RAFM and conventional RAFM steels have been investigated, such as friction stir welding (FSW) [5, 6], diffusion welding (hot hydrostatic pressing or hot isostatic pressing (HIP)) [7, 8], and electron beam welding (EBW) $[9,10]$. FSW shows good weld-ability but has geometry restrictions. HIP and EBW are believed to be potential technologies to join blanket structures [10]. In our previous work, effect of post-weld heat treatment (PWHT) on microstructure was studied on a dissimilar joint of RAFM steels between 9Cr-ODS and JLF-1 which was tentatively HIPed at $1000^{\circ} \mathrm{C}$ under $191 \mathrm{MPa}$ for $3 \mathrm{~h}$ with a slow cooling rate [8]. However, the proper temperature window during HIP is still remained to be investigated. In this

author'se-mail: fu.haiying@ms.nifs.ac.jp, haigirl1983@gmail.com

*) This article is based on the presentation at the 24th International Toki Conference (ITC24). work, joints between 9Cr-ODS and JLF-1 were made by HIP at higher temperatures of $1050^{\circ} \mathrm{C}$ and $1100^{\circ} \mathrm{C}$ to improve the joining properties such as strength and reduction of area. Because the high temperature may disrupt microstructure of the joints, PWHT was carried out to recover the microstructure and mechanical properties. Furthermore, EBW was also executed for comparison experiment. Evaluation of the joints made by different joining methods of HIP and EBW was discussed.

\section{Materials and Experimental Proce- dure}

Chemical composition of the materials was Fe-9.08Cr-0.14C-1.97W-0.23Ti-0.29Y-0.16O-0.013N for 9Cr-ODS and Fe-9.00Cr-0.090C-1.98W-0.20V-0.083Ta$0.015 \mathrm{~N}$ for JLF-1, respectively. The final heat treatments of the as-received materials were normalized at $1050^{\circ} \mathrm{C}$ for $1 \mathrm{~h}$ for both, followed by tempering at $800^{\circ} \mathrm{C}$ for $1 \mathrm{~h}$ for $9 \mathrm{Cr}$-ODS and at $780^{\circ} \mathrm{C}$ for $1 \mathrm{~h}$ for JLF-1. The microstructure of both them is tempered martensite. 9Cr-ODS disks used for HIP were $5 \mathrm{~mm}$ thick and $24 \mathrm{~mm}$ in diameter. JLF-1 blocks were $20 \mathrm{~mm}$ thick and $24 \mathrm{~mm}$ in diameter. For each HIP group, one 9Cr-ODS disk was sandwiched between two JLF-1 blocks and sealed into a soft steel capsule using EBW. HIP was carried out under a pressure of $191 \mathrm{MPa}$ for 3 hours at $1000^{\circ} \mathrm{C}, 1050^{\circ} \mathrm{C}$, and $1100^{\circ} \mathrm{C}$, respectively. The cooling rate of the HIP 
was $5^{\circ} \mathrm{C} / \mathrm{min}$. PWHT was carried out for the joints at $1050^{\circ} \mathrm{C}$ for $1 \mathrm{~h}$ for normalization $(\mathrm{N})$ and $780^{\circ} \mathrm{C}$ for $1 \mathrm{~h}$ for tempering $(\mathrm{T})$ with a fast cooling rate of $34 \sim 36^{\circ} \mathrm{C} / \mathrm{min}$, to recover the microstructure to that before HIP according to the previous experience [8]. On the other hand, blocks for $9 \mathrm{Cr}-\mathrm{ODS}$ and JLF-1 for EBW were $5 \mathrm{~mm}$ in thickness, $20 \mathrm{~mm}$ in length, and $40 \mathrm{~mm}$ in width. EBW was carried out for butt-welding at $150 \mathrm{~V} / 15 \mathrm{~mA}$ with the speed of $2000 \mathrm{~mm} / \mathrm{min}$. PWHT at $780^{\circ} \mathrm{C}$ for $1 \mathrm{~h}$ for tempering (T) was carried out to relieve the hardening of the heat-affected zones (HAZs) and weld metal (WM).

Coupon specimens $(0.5 \mathrm{~mm} \times 5 \mathrm{~mm} \times 20 \mathrm{~mm})$ and tensile specimens (gauge size $0.25 \mathrm{~mm} \times 1.2 \mathrm{~mm} \times 5 \mathrm{~mm}$ ) were machined for the joints, which provided with the joining interface (for HIP joints) or weld metal (for EBW joint) located in the center of the specimens. Hardness tests were carried out at $100 \mathrm{gf}$ for $30 \mathrm{~s}$ for the coupon specimens before and after PWHT. Microstructure analysis with scanning electron microscopy (SEM) was conducted for the coupon specimens after etching with picric acid. Tensile tests were executed at room temperature (RT) and $550^{\circ} \mathrm{C}$ with initial strain rate of $6.7 \times 10^{-4} \mathrm{~S}^{-1}$. Fracture surfaces after tensile tests were also observed by SEM to determine reduction of area of the joints which were fractured at the interface.

\section{Results and Discussion}

\subsection{Effect of HIP temperature and PWHT on the joints}

Figure 1 shows the hardness of 9Cr-ODS and JLF-1 after HIP and the following PWHT. Hardness before HIP is about $350 \mathrm{HV}$ for $9 \mathrm{Cr}-\mathrm{ODS}$, about $210 \mathrm{HV}$ for JLF-1 (dashed lines in Fig. 1). Hardness of JLF-1 base metals exceeds $400 \mathrm{HV}$ after HIP. HIP induced quenched martensite for JLF-1. As-mentioned in [8], $\mathrm{HIP}$ at $1000^{\circ} \mathrm{C}$ is not enough for 9Cr-ODS base metal to induce quenched martensite. However, HIP at higher temperatures of $1050^{\circ} \mathrm{C}$ and $1100^{\circ} \mathrm{C}$ may induce quenched martensite for 9Cr-ODS, the hardness increased to about $450 \mathrm{HV}$. Note that, for all the as-HIPed conditions, the interface is the softest compared to the base metals of 9Cr-ODS and JLF1. For the $1000^{\circ} \mathrm{C}-\mathrm{HIP}$ joint, after PWHT with $\mathrm{N}$ or N\&T, the interface is still the softest. But after PWHT with $\mathrm{N}$ for the $1050^{\circ} \mathrm{C}$-HIP and $1100^{\circ} \mathrm{C}$-HIP joints, the hardness of the interface is comparable to that of the JLF-1 base metal. However, after PWHT with N\&T, JLF-1 base metal is the softest. And hardness of base metals 9Cr-ODS and JLF-1 has recovered similar to that before HIP.

Figure 2 depicts the tensile results at RT and $550^{\circ} \mathrm{C}$ for the as-HIPed joints and those after PWHT. It reveals that, the joints fractured at the softest site, where the hardness is the smallest, as shown the hardness results in Fig. 1. It can be seen that, $1000^{\circ} \mathrm{C}$ is not enough to join the joint well. All the joints fractured before yield point at interface with PWHT of N or N\&T. However, for the joints after
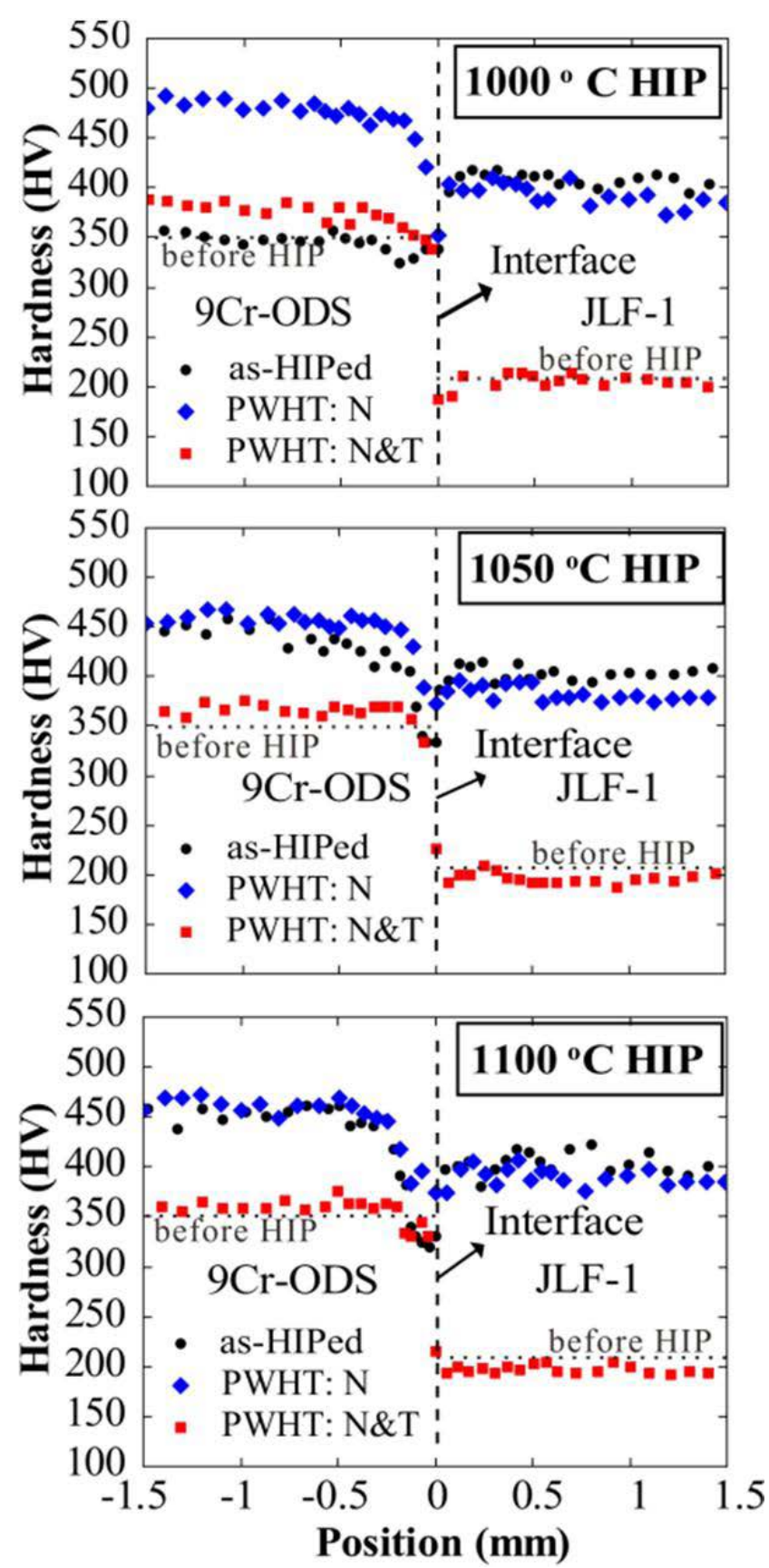

Fig. 1 Hardness of the joints HIPed at $1000^{\circ} \mathrm{C}, 1050^{\circ} \mathrm{C}, 1100^{\circ} \mathrm{C}$, and after PWHT with $\mathrm{N}$ and $\mathrm{N} \& \mathrm{~T}$.

HIP at $1050^{\circ} \mathrm{C}$ and $1100^{\circ} \mathrm{C}$, they fractured after yield point at the interface. In this study, normalized joining strength of the joints is defined as the ratio between load and area when fractured, N/A. The joining strength and reduction of area for the $1050^{\circ} \mathrm{C}$-HIP joint is the highest, as shown in Table 1. As the temperature increases, the joining strength and reduction of area decrease. HIP at $1100^{\circ} \mathrm{C}$ may induce coarse grains. This disrupts joining properties. $1050^{\circ} \mathrm{C}$ seems to be a proper HIP temperature to get good joining property with highest strength and reduction of area. After PWHT with N, the joint fractured at the JLF-1 base metal when tensile-tested at RT, but still fractured at interface 

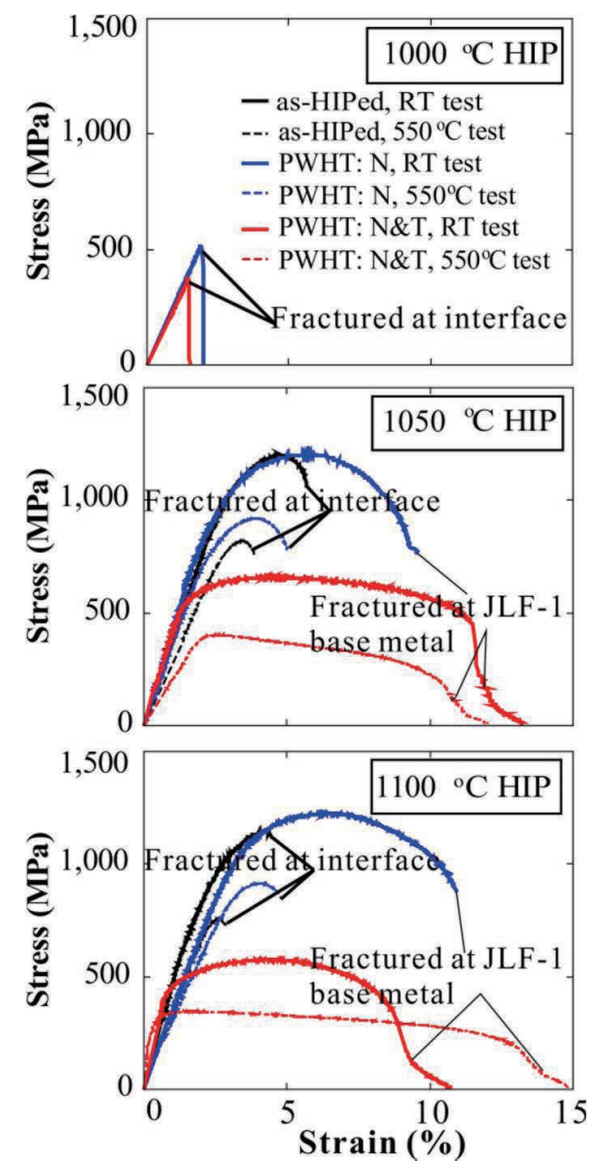

Fig. 2 Tensile curves of the HIPed joints before and after PWHT with $\mathrm{N}$ and N\&T.

Table 1 Tensile property of the HIPed joints.

\begin{tabular}{|l|l|l|l|l|}
\hline $\begin{array}{l}\text { HIP } \\
\text { temperature }\end{array}$ & Condition & $\begin{array}{l}\text { Test } \\
\text { temperature }\end{array}$ & $\begin{array}{l}\text { Normalized } \\
\text { joining strength }\end{array}$ & $\begin{array}{l}\text { Reduction } \\
\text { of area }\end{array}$ \\
\hline $1000{ }^{\circ} \mathrm{C}$ & PWHT: N & RT & $560 \mathrm{MPa}$ & $7.3 \%$ \\
\hline & PWHT: N\&T & RT & $410 \mathrm{MPa}$ & $9.8 \%$ \\
\hline $1050{ }^{\circ} \mathrm{C}$ & as-HIPed & RT & $1750 \mathrm{MPa}$ & $39 \%$ \\
\hline & as-HIPed & $550{ }^{\circ} \mathrm{C}$ & $1350 \mathrm{MPa}$ & $43 \%$ \\
\hline & PWHT: $\mathrm{N}$ & $550{ }^{\circ} \mathrm{C}$ & $2180 \mathrm{MPa}$ & $64 \%$ \\
\hline $1100{ }^{\circ} \mathrm{C}$ & as-HIPed & RT & $1320 \mathrm{MPa}$ & $15 \%$ \\
\hline & as-HIPed & $550{ }^{\circ} \mathrm{C}$ & $840 \mathrm{MPa}$ & $15 \%$ \\
\hline & PWHT: $\mathrm{N}$ & $550{ }^{\circ} \mathrm{C}$ & $1270 \mathrm{MPa}$ & $33 \%$ \\
\hline
\end{tabular}

when tested at $550^{\circ} \mathrm{C}$. After PWHT with N\&T, the joining strength is expected to be improved further. The joints fractured at JLF-1 base metal, not at the interface any more. The joining strength needs to be determined by four-point bending test in the future, which could concentrate stress precisely at the interface.

Figure 3 shows the microstructure of the interface HIPed at $1000-1100^{\circ} \mathrm{C}$ and after PWHT with N\&T. After HIP, JLF-1 base metal is quenched martensite structure without any carbides on lath and grain boundaries. However, coarse carbides (suspected as $\mathrm{M}_{3} \mathrm{C}[8,11]$ ) always exist on the grain boundaries of 9Cr-ODS as-HIPed due to

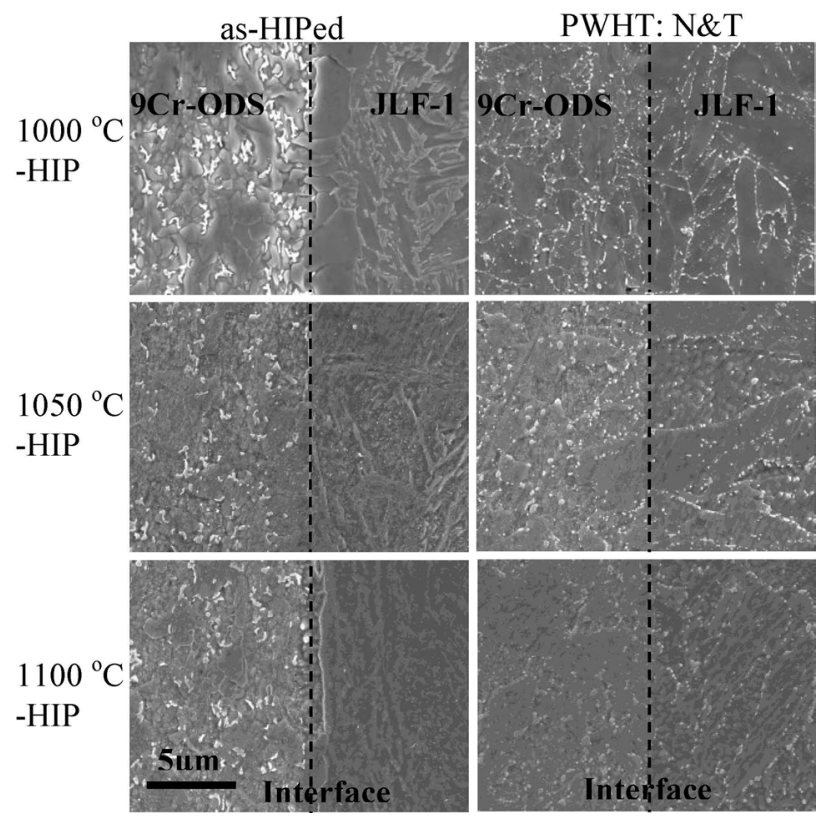

Fig. 3 Microstructure of the interface after HIP at $1000-1100^{\circ} \mathrm{C}$ and after PWHT with N\&T.

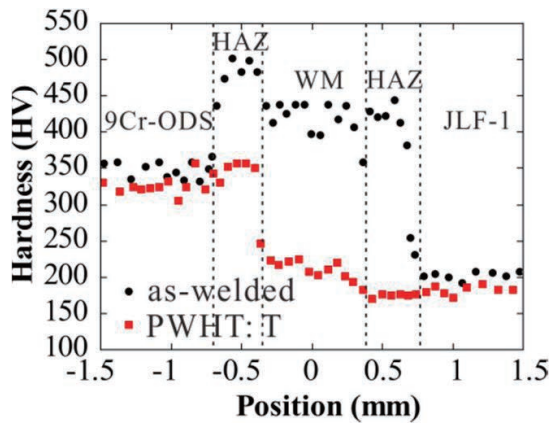

Fig. 4 Hardness of the EBW joint before and after PWHT.

the slow cooling rate of $5^{\circ} \mathrm{C} / \mathrm{min}$. After HIP at higher temperatures of $1050^{\circ} \mathrm{C}$ and $1100^{\circ} \mathrm{C}$, the carbides are fewer and smaller than those after HIP at $1000^{\circ} \mathrm{C}$. More elements may dissolved into matrix rather than in the carbides when HIP at higher temperatures. Thus the hardness after HIP at $1050-1100^{\circ} \mathrm{C}$ was higher than that after $\mathrm{HIP}$ at $1000^{\circ} \mathrm{C}$, as depicted in Fig. 1. After PWHT with N\&T, both $9 \mathrm{Cr}-$ ODS and JLF-1 was recovered to that before HIP of tempered martensite with $\mathrm{M}_{23} \mathrm{C}_{6}$ carbides on grain and lath boundaries. Thus, after PWHT, the joining properties of the joints were improved as shown in Fig. 2, where the tensile specimens fractured outside the interface.

\subsection{Effect of PWHT on the EBW joint}

After EBW, the WM and the both HAZs of 9Cr-ODS and JLF-1 are hardened, as shown in Fig. 4. After PWHT at $780^{\circ} \mathrm{C}$ for $1 \mathrm{~h}$ for tempering $(\mathrm{T})$, the hardening of the WM and HAZs is relieved. Figure 5 shows the microstructure of HAZs of 9Cr-ODS and JLF-1, and WM. For the as-welded condition, both HAZs of 9Cr-ODS and JLF-1 


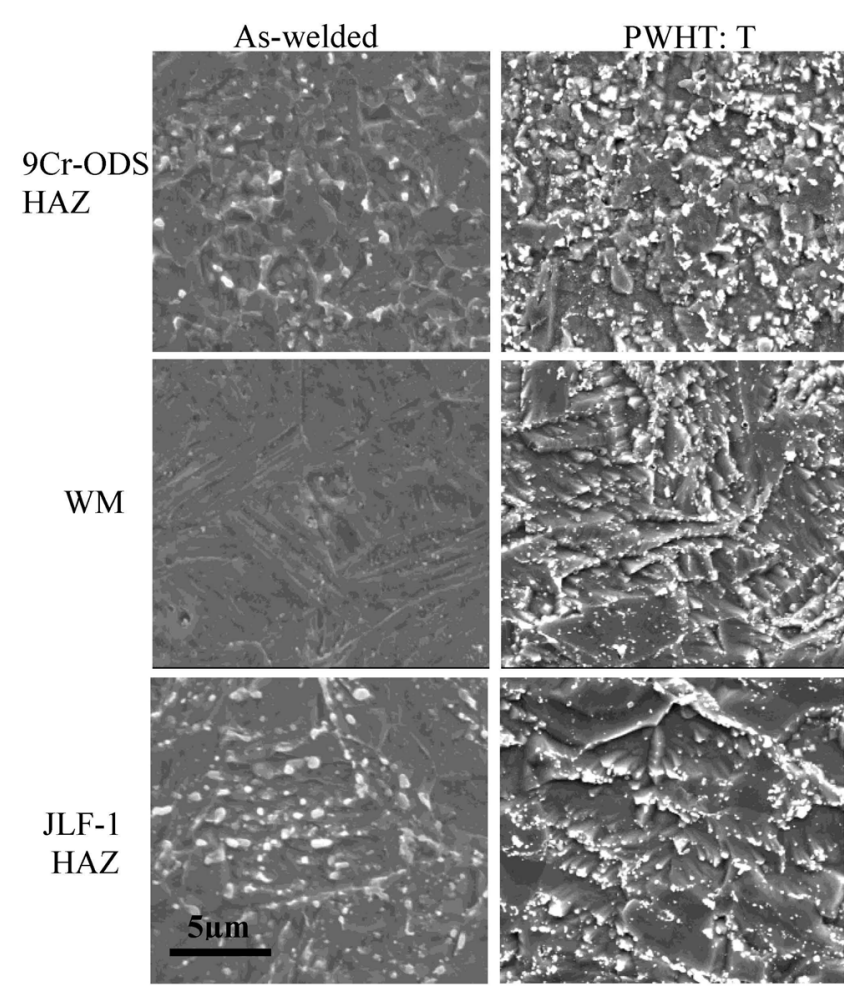

Fig. 5 Microstructure of HAZs of 9Cr-ODS and JLF-1, and WM before and after PWHT with tempering.

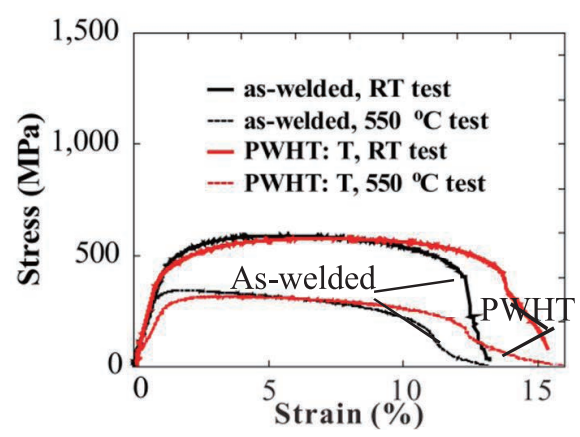

Fig. 6 Tensile curves of the EBW joint before and after PWHT with tempering.

are quenched martensite with carbides fewer than those in the base metals. WM is quenched martensite due to the rapid cooling after melting during the EBW process. After PWHT, WM and both HAZs of 9Cr-ODS and JLF-1 are tempered martensite with carbides on grain and lath boundaries. Thus, hardening of HAZs and WM is relieved.

Tensile results at $\mathrm{RT}$ and $550^{\circ} \mathrm{C}$ show that, the EBW joints before and after PWHT all fractured at the JLF-1 base metals, as shown in Fig. 6. Because of highly concentrated energy input, 9Cr-ODS and JLF-1 was joined by liquid-phase diffusion process. The weld-ability of the joint made by EBW is superior to those by HIP with solidstate diffusion process. However, after PWHT, the tensile properties of the HIPed joints were comparable to the EBW joint.

\section{Conclusion}

In this work, HIP and EBW were utilized for the dissimilar joining of 9Cr-ODS and JLF-1 for the research of fusion application. The summary is drawn as follows,

(1) $1050^{\circ} \mathrm{C}$ is a proper temperature for the HIP to get good joining strength and reduction of area. PWHT with N\&T is expected to get better joining property further, which could be comparable to that made by EBW.

(2) HIP with a slow cooling rate could induce microstructure with coarse carbides (suspected as $\mathrm{M}_{3} \mathrm{C}$ ) for 9Cr-ODS. This could be recovered to normal carbides $\mathrm{M}_{23} \mathrm{C}_{6}$ by PWHT with N\&T.

(3) HIP is a good technique to weld large components with complicated shapes but has a drawback of weaker weld-ability. EBW has good weld-ability but with thickness limitation during welding. Multiple welding techniques could be utilized for the construction of fusion blanket systems by taking full advantage of PWHT.

\section{Acknowledgements}

This work was supported by NIFS budget codes NIFSUFFF024 and NIFSKOBF020.

[1] S. Ukai, in Comprehensive Nuclear Materials, edited by R. J. M. Konings (Elsevier, Oxford, 2012), pp.241-271.

[2] T. Tanno, S. Ohtsuka, Y. Yano, T. Kaito, Y. Oba, M. Ohnuma, S. Koyama and K. Tanaka, J. Nucl. Mater. 440, 568 (2013).

[3] Y. Li, T. Nagasaka, T. Muroga, A. Kimura and S. Ukai, Fusion Eng. Des. 86, 2495 (2011).

[4] S. Ukai and M. Fujiwara, J. Nucl. Mater. 307-311, Part 1, 749 (2002).

[5] D.T. Hoelzer, K.A. Unocic, M.A. Sokolov and Z. Feng, J. Nucl. Mater. 442, S529 (2013).

[6] T. Uwaba, S. Ukai, T. Nakai and M. Fujiwara, J. Nucl. Mater. 367-370, Part B, 1213 (2007).

[7] S. Noh, B. Kim, R. Kasada and A. Kimura, J. Nucl. Mater. 426, 208 (2012).

[8] H.Y. Fu, T. Nagasaka, T. Muroga, A. Kimura and J.M. Chen, Fusion Eng. Des. 89, 1658 (2014).

[9] L. Commin, M. Rieth, V. Widak, B. Dafferner, S. Heger, H. Zimmermann, E. Materna-Morris and R. Lindau, J. Nucl. Mater. 442, S552 (2013).

[10] R. Lindau, M. Klimenkov, U. Jäntsch, A. Möslang and L. Commin, J. Nucl. Mater. 416, 22 (2011).

[11] W.D. Callister, Fundamentals of Materials Science and Engineering: An Integrated Approach, 4 edition (Wiley, Hoboken, N.J, 2012). 